REVIEW

\title{
Cannabinoids for clinicians: the rise and fall of the cannabinoid antagonists
}

\author{
Helen Butler and Márta Korbonits \\ Department of Endocrinology, Barts and the London School of Medicine, Queen Mary University of London, Charterhouse Square, London EC1M 6BQ, UK \\ (Correspondence should be addressed to M Korbonits; Email: m.korbonits@qmul.ac.uk)
}

\begin{abstract}
The endocannabinoid system has emerged as a significant player in the control of energy balance and metabolism, through its direct central and peripheral effects, as well as via its interaction with other appetite-regulating pathways. There is mounting evidence that the endocannabinoid system is overactive in obesity and were it possible to safely dampen-down the elevated endocannabinoid tone, lipid and carbohydrate profiles could be improved and weight loss induced. The series of randomised clinical trials showed reproducible beneficial effects on weight, HbA1c and lipid parameters, in addition to other cardiovascular risk factors. However, to date, clinical developments have been halted because of psychiatric side effects. Although recent evidence has highlighted the importance of an appetiteindependent, peripheral mode of action, it is still unclear whether selectively blocking the peripheral system could potentially solve the problem of the central side effects, which thus far has led to the demise of the cannabinoid antagonists as useful pharmaceuticals. In this concise review, we summarise the data on the metabolic effects of the cannabinoid pathway and its antagonists.
\end{abstract}

European Journal of Endocrinology $161655-662$

\section{Introduction}

The endocannabinoid system is a complex physiologic system that is highly relevant in the control of energy balance and metabolism (1). Upon stimulation, it increases food intake and weight gain, promotes lipogenesis and impairs glucose tolerance (2). There is growing evidence that the endocannabinoid system is overactive in obesity $(3,4)$, and thus targeting and suppressing the system could result in a potential pathway by which to treat obesity, type 2 diabetes and the metabolic syndrome. Despite the early promising results of the cannabinoid antagonists, the drug's side effect profile regarding depression and suicidal risk has been deemed unsafe, and thus, to date, all preparations have been withdrawn from trials or clinical practice. Here, we discuss the discovery, physiology and mechanism of action of the endocannabinoid system, along with its potential for manipulation in the treatment of obesity.

\section{The discovery and physiology of the endocannabinoids}

The plant Cannabis sativa has been used to promote caloric intake by enhancing appetite for hundreds of years $(5,6)$. Despite knowledge of its medical benefits for centuries, it was not until 1964 that the psychoactive component of cannabis was isolated as
$\Delta$-9-tetrahydrocannabinol (7), which subsequently led to the discovery and cloning of two specific $\mathrm{G}_{\mathrm{i} / \mathrm{o}}$ proteincoupled cannabinoid receptors, $\mathrm{CB}_{1}(8)$ and $\mathrm{CB}_{2}(9)$. Both receptors are expressed in the CNS, as well as in peripheral tissues. $\mathrm{CB}_{1}$ was found to be one of the most prevalent $\mathrm{G}$ protein-coupled receptors in the mammalian brain, while $\mathrm{CB}_{2}$ was shown to have prominent roles in immune and haematopoietic cells, as well as osteoblasts and osteoclasts (10-13). The discovery of specific cannabinoid receptors implied that endogenous ligands capable of activating these receptors must exist. Anandamide and 2-arachidonoylglycerol (2-AG) are the two most widely studied 'endocannabinoids'. They are not stored in vesicles like other neurotransmitters, but produced on demand by $\mathrm{Ca}^{2+}$-induced enzymatic cleavage from phospholipid precursors (14). $\mathrm{CB}_{1}$ receptors are often localised on pre-synaptic neurons, which suggest retrograde signal transmission (15) (Fig. 1), whereby the endocannabinoids usually act to reduce neuronal excitability via inhibitory effects on voltage-gated $\mathrm{Ca}^{2+}$ channels and the activation of $\mathrm{K}^{+}$ channels (16) (Fig. 2). In addition to $\mathrm{CB}_{1}$ and $\mathrm{CB}_{2}$, several other receptors were shown to be targets of endocannabinoids, including the transient receptor potential cation channel, subfamily $\mathrm{V}$, member 1 $\left(\mathrm{TPRV}_{1}\right)(17)$, a novel orphan cannabinoid receptor GPR 55 (18) and additional unidentified endothelial and cardiac receptors, which may mediate endocannabinoid-induced cardiovascular effects $(19,20)$. non-commercial use, distribution, and reproduction in any medium, provided the original work is properly cited. 


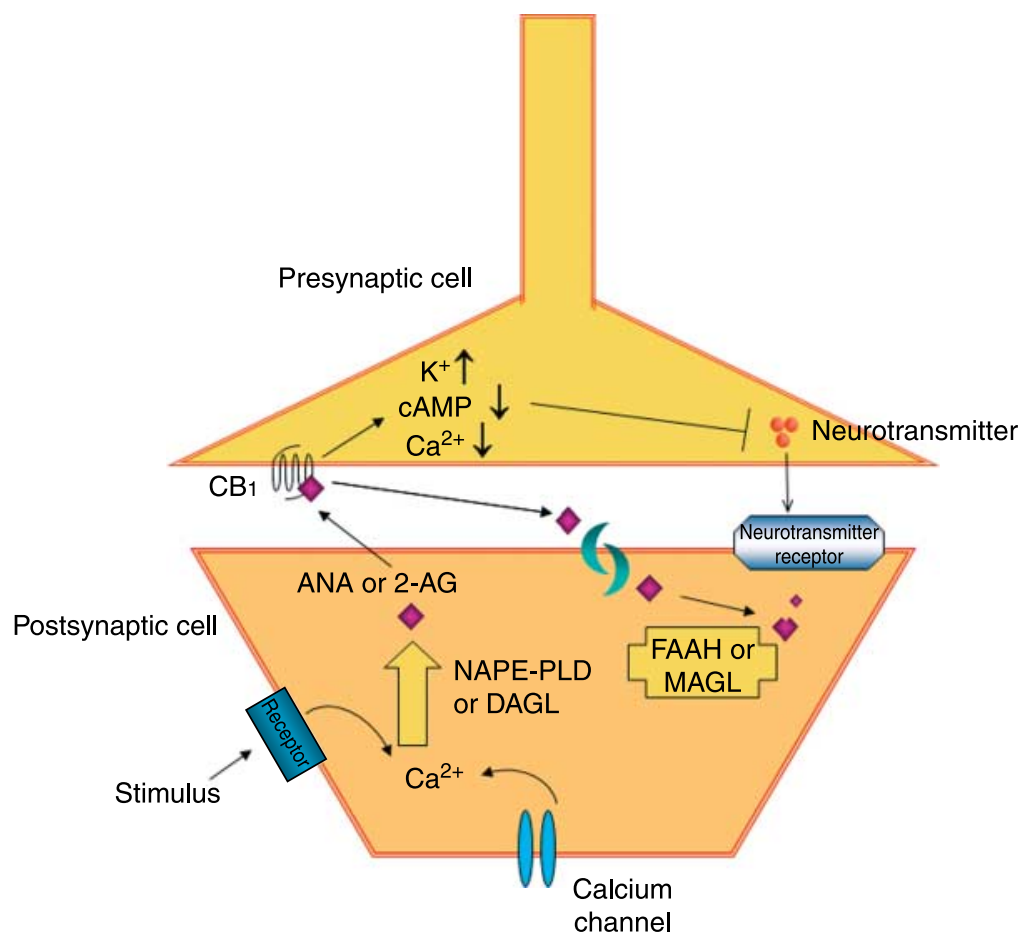

Figure 1 Upon stimulation of the postsynaptic cell, an influx of intracellular calcium results in the activation of $\mathrm{N}$-acylphosphatidylethamolamine hydrolysing phospholipase D (NAPE-PLD) and diacyl-glycerol lipase (DAGL- $\alpha$ and $-\beta$ ) and release of endocannabinoids (e.g. anandamide (ANA) or 2-arachidonoylglycerol (2-AG)) from the postsynaptic terminal. The endocannabinoid crosses the synaptic cleft and binds to its receptor on the presynaptic terminal. Cannabinoid receptor activation often results in blocked neurotransmitter release from the presynaptic neuron. The endocannabinoids are taken up by the postsynaptic cell via a method of unspecified transport (green crescents) and are finally inactivated and degraded by fatty acid amide hydrolase (FAAH) or monoacylglycerol lipase (MAGL) $(83,84)$.
The cannabinoids have wide ranging effects on various systems including mood, cognition and reward, immune, gastrointestinal and reproduction, sleep, neuroprotection, bone and cardiovascular function, in addition to appetite, lipid and carbohydrate metabolism (15). The orexigenic effect of the endocannabinoids is mediated via activation of AMP-activated protein kinase (AMPK) (21-23). AMPK plays a central role in the control of energy homeostasis both at an individual cellular level and that of the whole body via its appetite-stimulating effects in the hypothalamus. It can sense the cellular 'energy status' and upon activation causes the cell to switch from ATP consumption to ATP production. AMPK is known to be influenced by various stimuli such as leptin, ghrelin, adiponectin and $\alpha$-melanocortin-stimulating hormone, as well as metformin and glitazones (24).

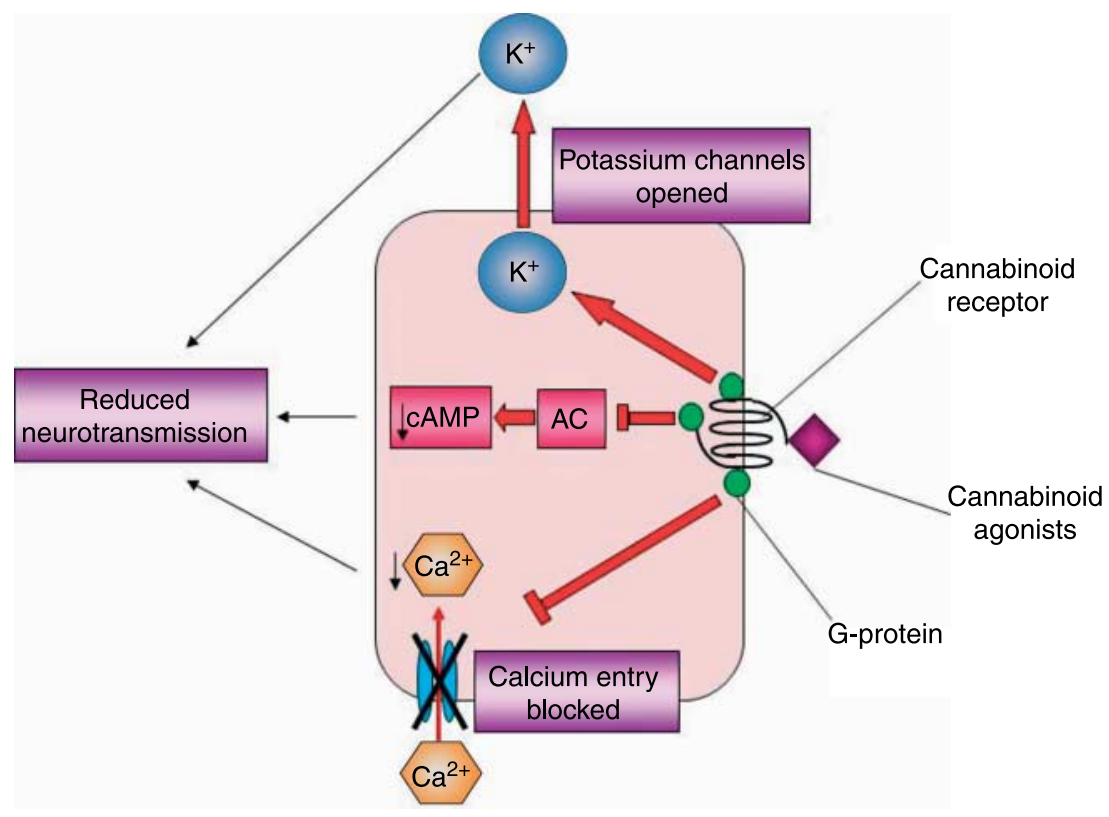

Figure 2 Cannabinoid receptor activation often leads to reduced cellular neurotransmission by blocking $\mathrm{Ca}^{2+}$ entry, via hyperpolarisation, as a result of $\mathrm{K}^{+}$channel activation, or by reduced cAMP generation. 


\section{Interaction with other hormones and systems}

It seems that cannabinoids interact with a number of hormonal systems and possibly mediate their effects. Data for heterodimerisation of the receptor with the orexin (25), type 2 dopamine (26) and opioid receptors (27) have been shown, and possible other partners have been suggested, such as the ghrelin receptor (28) (Table 1).

\section{Mode of action: central versus peripheral}

Initially, it was thought that the endocannabinoid system acted solely centrally through its effects on appetite and food intake. In support of this, the $\mathrm{CB}_{1}$ receptor is widely prevalent centrally $(8,42)$, and central administration of anandamide into the ventromedial nucleus causes hyperphagia in rats (22). However, the endocannabinoids not only act centrally but also peripherally in the control of energy balance and metabolism. $\mathrm{CB}_{1}$ receptors have been found peripherally on the nerve terminals of gastrointestinal tract neurons (43), liver (44), skeletal muscle (45), pancreas (46) and in adipose tissue (47). Upon pair feeding of $\mathrm{CB}_{1}$ knockout $\left(\mathrm{CB}_{1}^{-1-}\right)$ mice with normal littermates, wild-type mice gained weight, while the $\mathrm{CB}_{1}^{-1-}$ did not, despite the same caloric intake (48). Similarly, chronic injection of a $\mathrm{CB}_{1}$ receptor antagonist in obese rodents caused significant weight loss, which was sustained despite only a transient decrease in caloric intake (49). A human study showed an increase in caloric intake and weight gain in volunteers who smoked cannabis when compared with controls (50); interestingly, although the weight of the participants continued to increase throughout the 3-week study, the increased food intake subsided after just a few days.
This suggests that the cannabinoids increase weight by methods other than solely stimulating appetite. In addition, food deprivation leads to a sevenfold increase in intestinal levels of anandamide, and this effect is reversed upon refeeding. When the neurotoxin capsaicin was used to destroy the sensory afferent fibres of the gut, the effects of peripherally administered anandamide were abolished. This is supportive of a peripheral mechanism of action, whereby anandamide acts on peripheral $\mathrm{CB}_{1}$ receptors located on the sensory nerve terminals of the gut to create its hyperphagic effect (51). Furthermore, experimental evidence on adipose tissue has shown that, in addition to $\mathrm{CB}_{1}$ receptors, enzymes regulating the biosynthesis and degradation of the endocannabinoids are present, and the levels of endocannabinoids in adipose tissue were found to be similar to those of the brain (52). This is probably due to an increase in the fat oxidation rate. First, this is supported by a reduction in the respiratory quotient. Secondly, experiments in adipocytic cultures have shown that chronic $\mathrm{CB}_{1}$ blockade reduces adipose mass by increasing oxidation rate, via the induction of enzymes of $\beta$-oxidation and the Krebs cycle (53). Thirdly, in the opposite situation, adipocyte cultures treated with cannabinoid agonists show lipoprotein lipase activation (2) and decreased expression of adiponectin (54), which cause triglyceride reesterification and reduce fatty acid oxidation. Most of these effects can be explained by the inhibitory effect of cannabinoids on liver and adipose tissue AMPK activity (23). Osei-Hyiaman et al. investigated the role of the liver as a target for the peripheral regulation of energy metabolism by the endocannabinoids. When given a high-fat diet, the density of $\mathrm{CB}_{1}$ receptors increased, as did levels of hepatic anandamide. Upon activation, de novo fatty acid synthesis occurred (48) due to an increase in fatty acid synthase and acetyl-CoA carboxylase, thus promoting insulin resistance and hepatic steatosis (55).

Table 1 Interaction with other hormones and systems.

\begin{tabular}{|c|c|c|}
\hline Interacting partners & Effect & Reference \\
\hline Leptin & $\begin{array}{l}\text { - Leptin reduces endocannabinoid levels in the hypothalamus } \\
\text { - Leptin-deficient animals reduce food intake in response to a } \mathrm{CB}_{1} \text { antagonist } \\
\text { - Leptin-deficient animals have high endocannabinoid levels } \\
\text { - Anorexia nervosa patients have high circulating endocannabinoid levels }\end{array}$ & $(30-33)$ \\
\hline Ghrelin & $\begin{array}{l}\text { - Ghrelin increases endocannabinoid levels in the hypothalamus } \\
\text { - Intact } \mathrm{CB}_{1} \text { is necessary for ghrelin appetite and AMPK effects in the hypothalamus }\end{array}$ & (28) \\
\hline Adiponectin & $\begin{array}{l}\text { - } \mathrm{CB}_{1} \text { antagonist increases adiponectin levels } \\
\text { - The beneficial effects of } \mathrm{CB}_{1} \text { antagonist are partly (but not fully) via adiponectin }\end{array}$ & $(30,34)$ \\
\hline NPY, $\alpha \mathrm{MSH}$ & $\begin{array}{l}\text { - Anandamide increases hypothalamic neuropeptide } \mathrm{Y} \text {, an effect inhibited by } \\
\text { cannabinoid antagonists } \\
\text { - } \alpha \text {-MSH and the cannabinoid system have been shown to decrease food intake } \\
\text { synergistically }\end{array}$ & $(35-36)$ \\
\hline Orexin & $\begin{array}{l}\text { - Orexin receptor, OX1R, was shown to heterodimerise with the } \mathrm{CB}_{1} \text { receptor, leading } \\
\text { to increased orexin effects }\end{array}$ & $(25,37)$ \\
\hline Glucocorticoids & - Glucocorticoids release endocannabinoids in the hypothalamus & $(38,39,82)$ \\
\hline Neurotransmitters & $\begin{array}{l}\text { - The endocannabinoid system influences the release of various neurotransmitters, } \\
\text { including GABA, noradrenaline, dopamine, glutamate and acetylcholine } \\
\text { - A direct interaction of dopamine receptors and } \mathrm{CB}_{1} \text { has been suggested }\end{array}$ & $(29,40,41)$ \\
\hline
\end{tabular}


Treatment with a $\mathrm{CB}_{1}$ antagonist has been shown to reduce hepatic steatosis in rats (56), while results of treatment with rimonabant for non-alcoholic fatty liver disease in humans have been promising (57).

\section{Hyperactivity of the endocannabinoid system in obesity}

Both animal and human data show that the endocannabinoid system is up-regulated in obesity (58). A significantly higher amount of 2-AG was found in visceral fat in obese and overweight individuals when compared with normal-weight controls (54). A study on obese, postmenopausal women showed raised 2-AG and anandamide levels, along with reduced fatty acid amide hydrolase (FAAH) expression compared with control subjects (59), suggesting that impaired degradation of endocannabinoids could play a role. Further data to support the importance of endocannabinoid degradation showed that a missense polymorphism in FAAH was found to correlate with body mass index (BMI) in obese patients (60). Those with the polymorphism had only half the FAAH enzymatic activity of controls, thus providing substantial evidence for an upregulation of the endocannabinoid system in obesity due to, at least in part, a defect in the mechanism of degradation (60). However, these data were not reproduced in a similar study, which included over 5000 patients (61). Polymorphisms of the CNR1 gene encoding the $\mathrm{CB}_{1}$ receptor have also been shown to be associated with obesity (62).

\section{Manipulating the system}

The hyperactive endocannabinoid system in obesity has been targeted, using $\mathrm{CB}_{1}$ receptor antagonists, in an attempt to attenuate endocannabinoid signalling. Animal studies have shown that by blocking the $\mathrm{CB}_{1}$ receptor, both food intake and weight are significantly reduced $(22,49,63,64)$. Following on from these promising results, Sanofi-Aventis commenced human clinical trials to test the safety and efficacy of rimonabant in the treatment of obesity (65). The rimonabant in obesity (RIO) trials, with over 6600 participants, composed of four separate trials: RIO North America (66), RIO Europe (67), RIO Diabetes (68) and RIO Lipids (69), all published in distinguished journals. Inclusion criteria for the RIO Europe and RIO North America trials included a BMI $>30 \mathrm{~kg} / \mathrm{m}^{2}$ or a BMI $>27 \mathrm{~kg} / \mathrm{m}^{2}$ with obesity-induced disease $(66,67)$. The RIO Lipids trial involved hyperlipidaemic, overweight and obese participants who had previously had no medical therapy, while the RIO Diabetes trial included type 2 diabetic patients on monotherapy, who were also overweight or obese. At 1-year follow-up, the results of the randomised, double-blind, placebo-controlled trials showed a placebo-corrected weight loss of $4.7 \mathrm{~kg}$ (range 4.1-5.4) in the $20 \mathrm{mg}$ group in RIO North America and $4.8 \mathrm{~kg}$ (3.9-5.7) in RIO Europe. RIO Lipids reported a weight loss of $5.4 \mathrm{~kg}$ (4.6-6.3), and RIO Diabetes result was $3.9 \mathrm{~kg}$ (3.2-4.6) (66-69). Furthermore, HbAlc and triglyceride levels decreased, while high density lipoprotein cholesterol increased. Waist circumference was also measured in the RIO trials and resulted in statistically significant reductions in the $20 \mathrm{mg}$ groups $(6.1,6.5,7.1$ and $5.2 \mathrm{~cm}$ respectively) compared with placebo (2.5, 2.4, 2.4 and $1.9 \mathrm{~cm}$ respectively). Further studies commenced including type 2 diabetic patients with no previous drug treatment (70), patients on established diabetic treatment and patients with cardiovascular risks factors were specifically followed. These studies also resulted in positive outcomes (71). The data suggested that rimonabant was a promising agent, and thus it was licensed in the European Union (EU) as an anti-obesity drug and approved by National Institute for Health and Clinical Excellence for use in the UK. Its indications were as an adjunct to a healthy diet and exercise in obese patients (BMI $>30 \mathrm{~kg} / \mathrm{m}^{2}$ ) and for overweight adults (BMI $>27 \mathrm{~kg} / \mathrm{m}^{2}$ ) with associated risk factors, such as type 2 diabetes or dyslipidaemia (NICE: National Institute for Health and Clinical Excellence: Rimonabant for the treatment of overweight and obese patients: http://www.nice.org.uk 2007).

However, a high incidence of adverse effects was reported in the RIO trials' $20 \mathrm{mg}$ groups. The most common side effects reported were headache, nausea, anxiety and depressed mood (69). Withdrawal rates were $15.0,14.5,12.8$ and $15.0 \%$ respectively in the four trials, compared with placebo withdrawal rates of $7.0,9.2,7.2$ and $5.5 \%$ (72). Because of the psychotropic nature of cannabis, psychiatric side effects are biologically plausible, and indeed $26 \%$ of participants in the $20 \mathrm{mg}$ groups reported psychiatric symptoms. These included depression, anxiety, sleep disorders and suicidal ideation (70). However, data suggest that in real-life clinical practice, $\sim 50 \%$ of individuals seeking treatment for obesity also suffer from depression, making it hard to ascertain whether or not reports of depression were attributable to the drug or not $(73,74)$.

As a result of the psychiatric side effect profile, the US Food and Drug Administration declined permission for rimonabant, and in October 2008, rimonabant was also suspended across the EU. The European Medicines Agency (EMEA) disputed its psychiatric safety, due to an increased risk of depression and significant suicide risk. Their analysis showed an approximately doubled risk of psychiatric disorders, including depression, anxiety, sleep disturbance and suicidal ideation, in those taking rimonabant when compared with placebo. Since the withdrawal of rimonabant, other $\mathrm{CB}_{1}$ antagonist drugs have also been halted in the process of development. Taranabant (Merck \& Co.) has been shown to induce chronic weight loss in diet-induced obese rats $(75,76)$. In a human trial, treatment with $12 \mathrm{mg}$ taranabant resulted in a significant increase in 
resting energy expenditure, most likely due to an increase in the fat oxidation rate, supported by a reduction in the respiratory quotient when taking the drug (77). Although the drug reached phase-III human obesity trials, they were stopped in October 2008, due to a high level of central side effects, including anxiety and depression (EMEA. The European Medicines Agency recommends suspension of the marketing authorisation of Acomplia: http://www.emea.europa.eu 2008).

Rimonabant has high affinity binding for the $\mathrm{CB}_{1}$ receptor and acts as a full inverse agonist. An alternative would be the use of a partial agonist, which would decrease cannabinoid receptor activation as well as preventing the psychiatric side effects evident when completely blocking $\mathrm{CB}_{1}$ (78). Partial agonists are reported to have a lower prevalence of adverse effects than either antagonists or inverse agonists, without reducing the efficacy of the drug (79). An example of such a drug with the potential for an anti-obesity effect is the $5-\mathrm{HT}_{6}$ ligand, E-6837 (80). The use of partial agonists at pharmacological targets in the endocannabinoid system may produce the significant weight loss results of the cannabinoid antagonists, but without the psychiatric side effects. Data is available on a neutral $\mathrm{CB}_{1}$ cannabinoid antagonist, 5-(4-chlorophenyl)-1-(2,4dichlorophenyl)-3-hexyl-1H-1,2,4,-triazole-LH21 (81). Its lack of inverse agonist properties and low permeation of the blood-brain barrier resulted in an improved sideeffect profile when compared with inverse agonists.

\section{Conclusion}

The hyperactive endocannabinoid system established in obesity has been supported with strong evidence from both animal and human experiments, with the argument for a genetic basis especially interesting. Breaking down the system and blocking the endocannabinoid pathway at any level could potentially diminish its excessive activity and promote weight loss. The peripheral actions of the system are intriguing, and selectively blocking the peripheral receptors may hold the solution to preventing the central side effects, which thus far have led to the downfall of the cannabinoid antagonists in therapeutic medicine. However, it is currently unclear whether the beneficial effects on weight, as well as lipid and carbohydrate metabolism, would be upheld in this case, as convincing data of direct central regulation of peripheral metabolism are emerging.

\section{Declaration of interest}

The authors declare that there is no conflict of interest that could be perceived as prejudicing the impartiality of the research reported.

\section{Funding}

This work was supported by the Wellcome Trust (081922/Z/07/Z).

\section{References}

1 Piomelli D. The endocannabinoid system: a drug discovery perspective. Current Opinion in Investigational Drugs 20056 672-679.

2 Cota D, Marsicano G, Tschop M, Grubler Y, Flachskamm C, Schubert M, Auer D, Yassouridis A, Thone-Reineke C, Ortmann S, Tomassoni F, Cervino C, Nisoli E, Linthorst AC, Pasquali R, Lutz B, Stalla GK \& Pagotto U. The endogenous cannabinoid system affects energy balance via central orexigenic drive and peripheral lipogenesis. Journal of Clinical Investigation 2003112 423-431.

3 Duffy D \& Rader D. Endocannabinoid antagonism: blocking the excess in the treatment of high-risk abdominal obesity. Trends in Cardiovascular Medicine 200717 35-43.

4 Perkins JM \& Davis SN. Endocannabinoid system overactivity and the metabolic syndrome: prospects for treatment. Current Diabetes Reports $2008 \mathbf{8} 12-19$.

5 Paton WD. Cannabis and its problems. Proceedings of the Royal Society of Medicine 197366 718-721.

6 Zias J, Stark H, Sellgman J, Levy R, Werker E, Breuer A \& Mechoulam R. Early medical use of cannabis. Nature 1993363215.

7 Gaoni Y \& Mechoulam R. The isolation and structure of delta-1tetrahydrocannabinol and other neutral cannabinoids from hashish. Journal of the American Chemical Society 197193 217-224.

8 Matsuda LA, Lolait SJ, Brownstein MJ, Young AC \& Bonner TI. Structure of a cannabinoid receptor and functional expression of the cloned cDNA. Nature 1990346 561-564.

9 Munro S, Thomas KL \& Abu-Shaar M. Molecular characterization of a peripheral receptor for cannabinoids. Nature $1993 \mathbf{3 6 5} 61-65$.

10 Howlett AC, Barth F, Bonner TI, Cabral G, Casellas P, Devane WA, Felder CC, Herkenham M, Mackie K, Martin BR, Mechoulam R \& Pertwee RG. International Union of Pharmacology. XXVII. Classification of cannabinoid receptors. Pharmacological Reviews 200254 161-202.

11 Pertwee RG. The pharmacology of cannabinoid receptors and their ligands: an overview. International Journal of Obesity 2006 30 S13-S18.

12 Wittmann G, Deli L, Kallo I, Hrabovszky E, Watanabe M, Liposits Z \& Fekete C. Distribution of type 1 cannabinoid receptor $\left(\mathrm{CB}_{1}\right)$ immunoreactive axons in the mouse hypothalamus. Journal of Comparative Neurology 2007503 270-279.

13 Van Sickle MD, Duncan M, Kingsley PJ, Mouihate A, Urbani P, Mackie K, Stella N, Makriyannis A, Piomelli D, Davison JS, Marnett LJ, Di Marzo V, Pittman QJ, Patel KD \& Sharkey KA. Identification and functional characterization of brainstem cannabinoid $\mathrm{CB}_{2}$ receptors. Science 2005310 329-332.

14 Pacher P, Batkai S \& Kunos G. The endocannabinoid system as an emerging target of pharmacotherapy. Pharmacological Reviews 200658 389-462.

15 Pagotto U, Marsicano G, Cota D, Lutz B \& Pasquali R. The emerging role of the endocannabinoid system in endocrine regulation and energy balance. Endocrine Reviews 200627 73-100.

16 Howlett AC, Breivogel CS, Childers SR, Deadwyler SA, Hampson RE $\&$ Porrino LJ. Cannabinoid physiology and pharmacology: 30 years of progress. Neuropharmacology 200447 345-358.

17 Zygmunt PM, Petersson J, Andersson DA, Chuang H, Sorgard M, Di Marzo V, Julius D \& Hogestatt ED. Vanilloid receptors on sensory nerves mediate the vasodilator action of anandamide. Nature $1999400452-457$.

18 Ryberg E, Larsson N, Sjogren S, Hjorth S, Hermansson NO, Leonova J, Elebring T, Nilsson K, Drmota T \& Greasley PJ. The orphan receptor GPR 55 is a novel cannabinoid receptor. British Journal of Pharmacology 2007152 1092-1101.

19 Pacher P, Batkai S \& Kunos G. Blood pressure regulation by endocannabinoids and their receptors. Neuropharmacology 2005 48 1130-1138.

20 O'Sullivan SE, Kendall DA \& Randall MD. Characterisation of the vasorelaxant properties of the novel endocannabinoid $\mathrm{N}$-arachidonoyl-dopamine (NADA). British Journal of Pharmacology 2004 $141803-812$. 
21 Williams CM \& Kirkham TC. Anandamide induces overeating: mediation by central cannabinoid $\left(\mathrm{CB}_{1}\right)$ receptors. Psychopharmacology 1999143 315-317.

22 Jamshidi N \& Taylor DA. Anandamide administration into the ventromedial hypothalamus stimulates appetite in rats. British Journal of Pharmacology 2001134 1151-1154.

23 Kola B, Hubina E, Tucci SA, Kirkham TC, Garcia EA, Mitchell SE, Williams LM, Hawley SA, Hardie DG, Grossman AB \& Korbonits M. Cannabinoids and ghrelin have both central and peripheral metabolic and cardiac effects via AMP-activated protein kinase. Journal of Biological Chemistry $2005 \mathbf{2 8 0}$ 25196-25201.

24 Kola B. Role of AMP-activated protein kinase in the control of appetite. Journal of Neuroendocrinology 200820 942-951.

25 Ellis J, Pediani JD, Canals M, Milasta S \& Milligan G. Orexin-1 receptor-cannabinoid $\mathrm{CB}_{1}$ receptor heterodimerization results in both ligand-dependent and -independent coordinated alterations of receptor localization and function. Journal of Biological Chemistry $200628138812-38824$.

26 Kearn CS, Blake-Palmer K, Daniel E, Mackie K \& Glass M. Concurrent stimulation of cannabinoid $\mathrm{CB}_{1}$ and dopamine $\mathrm{D}_{2}$ receptors enhances heterodimer formation: a mechanism for receptor cross-talk? Molecular Pharmacology 200567 1697-1704.

27 Hojo M, Sudo Y, Ando Y, Minami K, Takada M, Matsubara T, Kanaide M, Taniyama K, Sumikawa K \& Uezono Y. mu-Opioid receptor forms a functional heterodimer with cannabinoid $\mathrm{CB}_{1}$ receptor: electrophysiological and FRET assay analysis. Journal of Pharmacological Sciences $2008 \mathbf{1 0 8} 308-319$.

28 Kola B, Farkas I, Christ-Crain M, Wittmann G, Lolli F, Amin F, Harvey-White J, Liposits Z, Kunos G, Grossman AB, Fekete C \& Korbonits M. The orexigenic effect of ghrelin is mediated through central activation of the endogenous cannabinoid system. PLoS ONE 20083 e1797.

29 Hermann H, Marsicano G \& Lutz B. Coexpression of the cannabinoid receptor type 1 with dopamine and serotonin receptors in distinct neuronal subpopulations of the adult mouse forebrain. Neuroscience 2002109 451-460.

30 Watanabe T, Kubota N, Ohsugi M, Kubota T, Takamoto I, Iwabu M, Awazawa M, Katsuyama H, Hasegawa C, Tokuyama K, Moroi M, Sugi K, Yamauchi T, Noda T, Nagai R, Terauchi Y, Tobe K, Ueki K \& Kadowaki T. Rimonabant ameliorates insulin resistance via both adiponectin-dependent and adiponectin-independent pathways. Journal of Biological Chemistry 2009284 1803-1812.

31 Monteleone P, Matias I, Martiadis V, De Petrocellis L, Maj M \& Di Marzo V. Blood levels of the endocannabinoid anandamide are increased in anorexia nervosa and in binge-eating disorder, but not in bulimia nervosa. Neuropsychopharmacology 200530 1216-1221.

32 Maccarrone M, Fride E, Bisogno T, Bari M, Cascio MG, Battista N, Finazzi Agro A, Suris R, Mechoulam R \& Di Marzo V. Up-regulation of the endocannabinoid system in the uterus of leptin knockout (ob/ob) mice and implications for fertility. Molecular Human Reproduction 200511 21-28.

33 Di Marzo V, Goparaju SK, Wang L, Liu J, Batkai S, Jarai Z, Fezza F, Miura GI, Palmiter RD, Sugiura T \& Kunos G. Leptin-regulated endocannabinoids are involved in maintaining food intake. Nature 2001410 822-825.

34 Bensaid M, Gary-Bobo M, Esclangon A, Maffrand JP, Le Fur G, Oury-Donat $\mathrm{F} \&$ Soubrie $\mathrm{P}$. The cannabinoid $\mathrm{CB}_{1}$ receptor antagonist SR141716 increases Acrp30 mRNA expression in adipose tissue of obese fa/fa rats and in cultured adipocyte cells. Molecular Pharmacology 200363 908-914.

35 Gamber KM, Macarthur H \& Westfall TC. Cannabinoids augment the release of neuropeptide $\mathrm{Y}$ in the rat hypothalamus. Neuropharmacology $200549646-652$.

36 Verty AN, McFarlane JR, McGregor IS \& Mallet PE. Evidence for an interaction between $\mathrm{CB}_{1}$ cannabinoid and melanocortin MCR-4 receptors in regulating food intake. Endocrinology $2004 \mathbf{1 4 5}$ 3224-3231.
37 Hilairet S, Bouaboula M, Carriere D, Le Fur G \& Casellas P. Hypersensitization of the orexin 1 receptor by the $\mathrm{CB}_{1}$ receptor: evidence for cross-talk blocked by the specific $\mathrm{CB}_{1}$ antagonist, SR141716. Journal of Biological Chemistry $2003 \mathbf{2 7 8}$ 23731-23737.

38 Di S, Malcher-Lopes R, Halmos KC \& Tasker JG. Nongenomic glucocorticoid inhibition via endocannabinoid release in the hypothalamus: a fast feedback mechanism. Journal of Neuroscience 200323 4850-4857.

39 Di S, Malcher-Lopes R, Marcheselli VL, Bazan NG \& Tasker JG. Rapid glucocorticoid-mediated endocannabinoid release and opposing regulation of glutamate and gamma-aminobutyric acid inputs to hypothalamic magnocellular neurons. Endocrinology $20051464292-4301$.

40 Marsicano G \& Lutz B. Expression of the cannabinoid receptor $\mathrm{CB}_{1}$ in distinct neuronal subpopulations in the adult mouse forebrain. European Journal of Neuroscience 199911 4213-4225.

41 Melis T, Succu S, Sanna F, Boi A, Argiolas A \& Melis MR. The cannabinoid antagonist SR 141716A (rimonabant) reduces the increase of extra-cellular dopamine release in the rat nucleus accumbens induced by a novel high palatable food. Neuroscience Letters 2007419 231-235.

42 Gerard CM, Mollereau C, Vassart G \& Parmentier M. Molecular cloning of a human cannabinoid receptor which is also expressed in testis. Biochemical Journal 1991279 129-134.

43 Croci T, Manara L, Aureggi G, Guagnini F, Rinaldi-Carmona M, Maffrand JP, Le Fur G, Mukenge S \& Ferla G. In vitro functional evidence of neuronal cannabinoid $\mathrm{CB}_{1}$ receptors in human ileum. British Journal of Pharmacology 1998125 1393-1395.

44 Osei-Hyiaman D, Liu J, Zhou L, Godlewski G, Harvey-White J, Jeong WI, Batkai S, Marsicano G, Lutz B, Buettner C \& Kunos G. Hepatic $\mathrm{CB}_{1}$ receptor is required for development of diet-induced steatosis, dyslipidemia, and insulin and leptin resistance in mice. Journal of Clinical Investigation $2008 \mathbf{1 1 8}$ 3160-3169.

45 Liu YL, Connoley IP, Wilson CA \& Stock MJ. Effects of the cannabinoid $\mathrm{CB}_{1}$ receptor antagonist SR141716 on oxygen consumption and soleus muscle glucose uptake in Lep(ob)/Lep(ob) mice. International Journal of Obesity 200529 183-187.

46 Juan-Pico P, Fuentes E, Bermudez-Silva FJ, Javier Diaz-Molina F, Ripoll C, Rodriguez de Fonseca F \& Nadal A. Cannabinoid receptors regulate $\mathrm{Ca}\left({ }^{2+}\right)$ signals and insulin secretion in pancreatic beta-cell. Cell Calcium 200639 155-162.

47 Despres JP. The endocannabinoid system: a new target for the regulation of energy balance and metabolism. Critical Pathways in Cardiology 20076 46-50.

48 Osei-Hyiaman D, DePetrillo M, Pacher P, Liu J, Radaeva S, Batkai S, Harvey-White J, Mackie K, Offertaler L, Wang L \& Kunos G. Endocannabinoid activation at hepatic $\mathrm{CB}_{1}$ receptors stimulates fatty acid synthesis and contributes to diet-induced obesity. Journal of Clinical Investigation 2005115 1298-1305.

49 Ravinet Trillou C, Arnone M, Delgorge C, Gonalons N, Keane P, Maffrand JP \& Soubrie P. Anti-obesity effect of SR141716, a $\mathrm{CB}_{1}$ receptor antagonist, in diet-induced obese mice. American Journal of Physiology. Regulatory, Integrative and Comparative Physiology 2003284 R345-R353.

50 Greenberg I, Kuehnle J, Mendelson JH \& Bernstein JG. Effects of marihuana use on body weight and caloric intake in humans. Psychopharmacology 1976 49 79-84.

51 Gomez R, Navarro M, Ferrer B, Trigo JM, Bilbao A, Del Arco I, Cippitelli A, Nava F, Piomelli D \& Rodriguez de Fonseca F. A peripheral mechanism for $\mathrm{CB}_{1}$ cannabinoid receptor-dependent modulation of feeding. Journal of Neuroscience $2002 \mathbf{2 2}$ 9612-9617.

52 Pagano C, Pilon C, Calcagno A, Urbanet R, Rossato M, Milan G, Bianchi K, Rizzuto R, Bernante P, Federspil G \& Vettor R. The endogenous cannabinoid system stimulates glucose uptake in human fat cells via phosphatidylinositol 3-kinase and calciumdependent mechanisms. Journal of Clinical Endocrinology and Metabolism 200792 4810-4819. 
53 Jbilo O, Ravinet-Trillou C, Arnone M, Buisson I, Bribes E, Peleraux A, Penarier G, Soubrie P, Le Fur G, Galiegue S \& Casellas $\mathrm{P}$. The $\mathrm{CB}_{1}$ receptor antagonist rimonabant reverses the diet-induced obesity phenotype through the regulation of lipolysis and energy balance. FASEB Journal 200519 1567-1569.

54 Matias I, Gonthier MP, Orlando P, Martiadis V, De Petrocellis L, Cervino C, Petrosino S, Hoareau L, Festy F, Pasquali R, Roche R, Maj M, Pagotto U, Monteleone P \& Di Marzo V. Regulation, function, and dysregulation of endocannabinoids in models of adipose and beta-pancreatic cells and in obesity and hyperglycemia. Journal of Clinical Endocrinology and Metabolism $2006 \mathbf{9 1}$ 3171-3180.

55 Jesudason D \& Wittert G. Endocannabinoid system in food intake and metabolic regulation. Current Opinion in Lipidology 200819 344-348.

56 Gary-Bobo M, Elachouri G, Gallas JF, Janiak P, Marini P, RavinetTrillou C, Chabbert M, Cruccioli N, Pfersdorff C, Roque C, Arnone M, Croci T, Soubrie P, Oury-Donat F, Maffrand JP, Scatton B, Lacheretz F, Le Fur G, Herbert JM \& Bensaid M. Rimonabant reduces obesity-associated hepatic steatosis and features of metabolic syndrome in obese Zucker fa/fa rats. Hepatology 200746 122-129.

57 Banasch M, Goetze O, Schmidt WE \& Meier JJ. Rimonabant as a novel therapeutic option for nonalcoholic steatohepatitis. Liver International 200727 1152-1155.

58 Di Marzo V \& Matias I. Endocannabinoid control of food intake and energy balance. Nature Neuroscience 20058 585-589.

59 Engeli S, Bohnke J, Feldpausch M, Gorzelniak K, Janke J, Batkai S, Pacher P, Harvey-White J, Luft FC, Sharma AM \& Jordan J. Activation of the peripheral endocannabinoid system in human obesity. Diabetes $2005542838-2843$.

60 Sipe JC, Waalen J, Gerber A \& Beutler E. Overweight and obesity associated with a missense polymorphism in fatty acid amide hydrolase (FAAH). International Journal of Obesity 200529 755-759.

61 Jensen DP, Andreasen CH, Andersen MK, Hansen L, Eiberg H, Borch-Johnsen K, Jorgensen T, Hansen T \& Pedersen O. The functional Pro129Thr variant of the FAAH gene is not associated with various fat accumulation phenotypes in a population-based cohort of 5,801 whites. Journal of Molecular Medicine $2007 \mathbf{8 5}$ 445-449.

62 Russo P, Strazzullo P, Cappuccio FP, Tregouet DA, Lauria F, Loguercio M, Barba G, Versiero M \& Siani A. Genetic variations at the endocannabinoid type 1 receptor gene (CNR1) are associated with obesity phenotypes in men. Journal of Clinical Endocrinology and Metabolism 200792 2382-2386.

63 Arnone M, Maruani J, Chaperon F, Thiebot MH, Poncelet M, Soubrie P \& Le Fur G. Selective inhibition of sucrose and ethanol intake by SR 141716, an antagonist of central cannabinoid $\left(\mathrm{CB}_{1}\right)$ receptors. Psychopharmacology 1997132 104-106.

64 Simiand J, Keane M, Keane PE \& Soubrie P. SR 141716, a CB cannabinoid receptor antagonist, selectively reduces sweet food intake in marmoset. Behavioural Pharmacology 19989 179-181.

65 Rinaldi-Carmona M, Barth F, Heaulme M, Shire D, Calandra B, Congy C, Martinez S, Maruani J, Neliat G, Caput D, Neliat G, Arnone M, Finance O, Soubrie P \& Le Fur G. SR141716A, a potent and selective antagonist of the brain cannabinoid receptor. FEBS Letters 1994350 240-244.

66 Pi-Sunyer FX, Aronne LJ, Heshmati HM, Devin J \& Rosenstock J. Effect of rimonabant, a cannabinoid-1 receptor blocker, on weight and cardiometabolic risk factors in overweight or obese patients: RIO-North America: a randomized controlled trial. Journal of the American Medical Association 2006295 761-775.

67 Van Gaal LF, Rissanen AM, Scheen AJ, Ziegler O \& Rossner S. Effects of the cannabinoid-1 receptor blocker rimonabant on weight reduction and cardiovascular risk factors in overweight patients: 1-year experience from the RIO-Europe study. Lancet $20053651389-1397$.
68 Scheen AJ, Finer N, Hollander P, Jensen MD \& Van Gaal LF. Efficacy and tolerability of rimonabant in overweight or obese patients with type 2 diabetes: a randomised controlled study. Lancet $20063 \mathbf{6 8} 1660-1672$.

69 Despres JP, Golay A \& Sjostrom L. Effects of rimonabant on metabolic risk factors in overweight patients with dyslipidemia. New England Journal of Medicine 2005353 2121-2134.

70 Nissen SE, Nicholls SJ, Wolski K, Rodes-Cabau J, Cannon CP, Deanfield JE, Despres JP, Kastelein JJ, Steinhubl SR, Kapadia S, Yasin M, Ruzyllo W, Gaudin C, Job B, Hu B, Bhatt DL, Lincoff AM \& Tuzcu EM. Effect of rimonabant on progression of atherosclerosis in patients with abdominal obesity and coronary artery disease: the STRADIVARIUS randomized controlled trial. Journal of the American Medical Association 2008299 1547-1560.

71 Scheen AJ \& Paquot N. Use of cannabinoid $\mathrm{CB}_{1}$ receptor antagonists for the treatment of metabolic disorders. Best Practice E Research. Clinical Endocrinology E Metabolism 2009 23 103-116.

72 Curioni C \& Andre C. Rimonabant for overweight or obesity. Cochrane Database of Systematic Reviews, 2006. Issue 4 CD006162.

73 Christensen R, Kristensen PK, Bartels EM, Bliddal H \& Astrup A. Efficacy and safety of the weight-loss drug rimonabant: a metaanalysis of randomised trials. Lancet $2007 \mathbf{3 7 0} 1706-1713$.

74 Cleland SJ \& Sattar N. Does rimonabant pull its weight for type 2 diabetes? Lancet $20063681632-1634$.

75 Lin LS, Lanza TJ Jr, Jewell JP, Liu P, Shah SK, Qi H, Tong X, Wang J, $\mathrm{Xu}$ SS, Fong TM, Shen CP, Lao J, Xiao JC, Shearman LP, Stribling DS, Rosko K, Strack A, Marsh DJ, Feng Y, Kumar S, Samuel K, Yin W, Van der Ploeg LH, Goulet MT \& Hagmann WK. Discovery of $N$-[(1S,2S)-3-(4-chlorophenyl)-2-(3-cyanophenyl)-1methylpropyl]-2-methyl-2-\{[5-(trifluoromethyl)pyridin-2-yl $]$ oxy $\}$ propanamide (MK-0364), a novel, acyclic cannabinoid-1 receptor inverse agonist for the treatment of obesity. Journal of Medicinal Chemistry $2006 \mathbf{4 9} 7584-7587$.

76 Fong TM, Guan XM, Marsh DJ, Shen CP, Stribling DS, Rosko KM, Lao J, Yu H, Feng Y, Xiao JC, Van der Ploeg LH, Goulet MT, Hagmann WK, Lin LS, Lanza TJ Jr, Jewell JP, Liu P, Shah SK, Qi H, Tong X, Wang J, Xu SS, Francis B, Strack AM, MacIntyre DE \& Shearman LP. Antiobesity efficacy of a novel cannabinoid-1 receptor inverse agonist, $N$-[(1S,2S)-3-(4-chlorophenyl)-2-(3-cyanophenyl)1-methylpropyl]-2-methyl-2-[[5-(trifluoromethyl)pyridin-2yl]oxy]propanamide (MK-0364), in rodents. Journal of Pharmacology and Experimental Therapeutics 2007321 1013-1022.

77 Addy C, Wright H, Van Laere K, Gantz I, Erondu N, Musser BJ, Lu K, Yuan J, Sanabria-Bohorquez SM, Stoch A, Stevens C, Fong TM, De Lepeleire I, Cilissen C, Cote J, Rosko K, Gendrano IN III, Nguyen AM, Gumbiner B, Rothenberg P, de Hoon J, Bormans G, Depre M, Eng WS, Ravussin E, Klein S, Blundell J, Herman GA, Burns HD, Hargreaves RJ, Wagner J, Gottesdiener K, Amatruda JM \& Heymsfield SB. The acyclic CB1R inverse agonist taranabant mediates weight loss by increasing energy expenditure and decreasing caloric intake. Cell Metabolism 2008 7 68-78.

78 Viveros MP, de Fonseca FR, Bermudez-Silva FJ \& McPartland JM. Critical role of the endocannabinoid system in the regulation of food intake and energy metabolism, with phylogenetic, developmental, and pathophysiological implications. Endocrine, Metabolic E Immune Disorders Drug Targets $2008 \mathbf{8} 220-230$.

79 Ohlsen RI \& Pilowsky LS. The place of partial agonism in psychiatry: recent developments. Journal of Psychopharmacology $200519408-413$.

80 Fisas A, Codony X, Romero G, Dordal A, Giraldo J, Merce R, Holenz J, Vrang N, Sorensen RV, Heal D, Buschmann H \& Pauwels PJ. Chronic 5-HT6 receptor modulation by E-6837 induces hypophagia and sustained weight loss in diet-induced obese rats. British Journal of Pharmacology 2006148 973-983.

81 Pavon FJ, Bilbao A, Hernandez-Folgado L, Cippitelli A, Jagerovic N, Abellan G, Rodriguez-Franco MA, Serrano A, Macias M, Gomez R, Navarro M, Goya P \& Rodriguez de Fonseca F. Antiobesity effects of the novel in vivo neutral cannabinoid receptor antagonist 5-(4-chlorophenyl)-1-(2,4-dichlorophenyl)-3-hexyl-1H-1,2,4-triazole - LH 21. Neuropharmacology 200651 358-366. 
82 Christ-Crain M, Kola B, Lolli F, Fekete C, Seboek D, Wittmann G, Feltrin D, Igreja SC, Ajodha S, Harvey-White J, Kunos G, Muller B, Pralong F, Aubert G, Arnaldi G, Giacchetti G, Boscaro M, Grossman AB \& Korbonits M. AMP-activated protein kinase mediates glucocorticoid-induced metabolic changes: a novel mechanism in Cushing's syndrome. FASEB Journal 200822 1672-1683.

83 Okamoto Y, Morishita J, Tsuboi K, Tonai T \& Ueda N. Molecular characterization of a phospholipase $\mathrm{D}$ generating anandamide and its congeners. Journal of Biological Chemistry 2004279 5298-5305.
84 Tsou K, Nogueron MI, Muthian S, Sanudo-Pena MC, Hillard CJ, Deutsch DG \& Walker JM. Fatty acid amide hydrolase is located preferentially in large neurons in the rat central nervous system as revealed by immunohistochemistry. Neuroscience Letters 1998 254 137-140.

Received 28 July 2009

Accepted 30 July 2009 